\title{
Lateral Bearing Trait in Indian Walnut (Juglans regia L.) Germplasm: a Potential Yield Contributing Trait in Early Age of the Tree
}

\author{
L. Chand ${ }^{1,2^{*}}$, D. B. Singh ${ }^{1}$, O. C. Sharma ${ }^{1}$, J. I. Mir ${ }^{1}$, K. L. Kumawat ${ }^{1}$, K. M. Rai ${ }^{1}$, S. A. Rather ${ }^{1}$, I. Qureshi ${ }^{1}$, S. Lal ${ }^{1}$ and Inder Dev ${ }^{2}$ \\ ${ }^{1}$ ICAR-Central Institute of Temperate Horticulture, Srinagar, Jammu and Kashmir (190 007), India \\ ${ }^{2}$ ICAR-Central Agroforestry Research Institute, Jhansi, U.P. (284 003), India
}

\section{Corresponding Author}

L. Chand

e-mail: godara.lal2009@gmail.com

\author{
Article History \\ Article ID: AR1840 \\ Received in $30^{\text {th }}$ August, 2017 \\ Received in revised form $25^{\text {th }}$ September, 2017 \\ Accepted in final form $4^{\text {th }}$ October, 2017
}

\begin{abstract}
The present study was carried out during year 2015 and 2016 at ICAR-Central Institute of Temperate Horticulture (CITH), Srinagar, India with the objective of trait specific characterization of walnut accessions with specific emphasis on lateral bearing trait. The study was initiated on pre-selected indigenous accessions collected from various pockets of North Western Himalaya and maintained at field gene bank of the institute. The most widely grown varieties 'Sulaiman' and 'Hamdan' were used as local check. All the accessions were monitored to identify the bearing habit. Only one accession CITH-W-121 (IC-0622836) was found with lateral bearing trait, which had fruit bearing on leafy shoots emerging from terminal, sub terminal as well as from lateral buds of 1-year-old shoot. Bearing on lateral leafy shoots developing from lateral buds of 1-year-old shoot is being reported for the first time in indigenous genetic resources of walnut which is an important trait to improve productivity. Lateral leafy shoots emerged all along 1-year old shoot, in which about $50 \%$ lateral leafy shoots bearing $1-3$ fruits panicle $^{-1}$. Overall 40-60\% lateral leafy shoots in a tree were bearing fruits in this accession. In term of yield, CITH-W-121 (11.07 kg tree-1) was found significantly superior to Sulaiman $\left(5.85 \mathrm{~kg} \mathrm{tree}^{-1}\right)$ and Hamdan $(5.48 \mathrm{~kg}$ tree-1). Yield efficiency was recorded significantly higher in CITH-W-121 (26.37 g cm${ }^{-2}$ tcsa) over the two ruling check varieties i.e, Hamdan (13.99 $\mathrm{g} \mathrm{cm}^{-2}$ tcsa) and Sulaiman (9.65 g cm-2 tcsa). In accession CITH-W-121, nut weight and kernel weight was recorded on par with Hamdan, while kernel recovery was on par with Sulaiman. This accession has desirable traits like well filled, plump and light coloured kernel with moderately easy removal of kernel halves and is having a good balance between vegetative growth and fruit bearing.
\end{abstract}

Keywords: Indian walnut, bearing habit, leafy shoot, yield

\section{Introduction}

Walnut (Juglans spp.) belongs to family Juglandaceae, order Fagales and is a diploid species $(2 n=32)$. The genus Juglans is broadly comprises of 21 species. The western Himalaya (WH) is the major producer region within India for walnut and has maximum variability for the species. The most commercially important walnut species, Persian or English walnut (Juglans regia $\mathrm{L}$.), is the only species found in the region (Rana et al., 2007). Walnut is cultivated since the era of Greek which is native to the region from the Balkans eastward to the Western Himalaya and cherished for its nutritious kernel and wood (Fernandez-Lopez et al., 2000). Walnut cultivation was found to be declining, mainly due to factors such as low productivity arising from a lack of good quality planting material, poor pollination, low tree density per unit area, predominant terminal bearing, long juvenile period, big tree size, poor filling, poor success rate of grafting, and climatic fluctuations (Rana et al., 2007). In walnut, continuous sexual propagation and natural cross pollination due to monoecism and heterodichogamy, has generated vast intra-species diversity in the WH region of the country. In India, genetic variability for nut and kernel characteristics in walnut has been reported by various researchers in the region (Sharma and Sharma, 1998; Sharma and Sharma, 2001; Pandey et al., 2004; Rana et al., 2007; Sharma et al., 2010). Richness of genetic variation in native walnut population presents many opportunities for selection and walnut improvement.

Walnut are monocious in nature, where male and female flowers borne at different location on the tree. Male flower develop from simple bud laterally on 1-year-old wood, while female flower develop generally in panicle of 1-3 flowers from mixed buds in which flowering take place at terminal position of current season's leafy shoot. On the basis of position of emergence of leafy shoot, walnut cultivars can be classified into three bearing group viz., terminal, intermediate and lateral (Germain, 1990). Fruit bearing habit is associated with 
branching density, position of flowering bud on annual shoots (Germain, 1990; Germain et al., 1992) and age of the fruiting shoot bearer (Solar et al., 2004). Each group of walnut varieties differ from the other in the branch number on its 1-yearold shoots (Ducousso et al., 1995). The bearing habit also influences tree structure and affects the productivity (Laurens et al., 2000). The lateral bearing is associated with precocity (Serr, 1962; Forde, 1979) and higher yield (McGranahan and Leslie, 1991; Solar et al., 2001). The lateral bud fruitfulness is considered as a most significant yield factor, which can also be manipulated through breeding (Akca and Ozongun, 2004). There is a need to select varieties having desirable traits, such as lateral bearing, dense branching, short stature, and earliness in bearing, good nut size and better nut-kernel ratio. Large germplasm collections, extent of variation in the collections and their accessibility to biologist and breeder are essential factor affecting their utilization in crop improvement programme. In view of the above facts, this study was initiated with the objective of identification of bearing habit with especial emphasis on lateral bearing trait, which was not reported earlier in this region.

\section{Materials and Methods}

\subsection{Experimental site}

A large collection including indigenous ( 350) and exotic (8) accessions of walnut is being maintained at field gene bank of ICAR-Central Institute of Temperate Horticulture (CITH), Srinagar, Jammu \& Kashmir, India. All the accessions were grafted on J. regia L. seedlings and planted during 2000-01 in field gene bank of institute which is located at $33^{\circ} 58^{\prime} \mathrm{N}$ latitude, $74^{\circ} 48^{\prime} \mathrm{E}$ longitude and at an altitude of $1643 \mathrm{~m}$ above mean sea level.

\subsection{Identification and quantification of lateral bearing}

The individual accessions were monitored regularly during fruiting season and focused on position of emergence of floriferous leafy shoots early in the season during year 2015 to identify the bearing habit. The trees of accession CITH-W-121 (IC-0622836) were found with heavy bearing as compared to others. To know this behavior, trees were observed many a time and literature was consulted. McGranahan and Leslie (2009) described that some cultivars produce female flowers on the tip of lateral shoots. This type of flowering is termed as lateral bearing or lateral bud fruitfulness and is associated with high yields when trees are young. On this basis, it was confirmed that CITH-W-121 is a lateral bearer, which bear fruit on lateral leafy shoots emerging all along 1-year-old shoots. Whereas, in terminal bearing cultivars, fruits are borne on leafy shoots arising only from terminal bud of 1-year-old shoots while in intermediate bearing cultivars, fruiting occurs on leafy shoots developing both from terminal as well as sub-terminal buds of 1-year-old shoots. Hence, forked branches appear on terminal end which promotes branching and provides more fruiting terminals. It is better to say that irrespective of bearing habit, inflorescence always appear on tip of current season's leafy shoot.

Age of branch in walnut tree was confirmed by rings present between one and two year old growth. Then, observations on percent lateral bearing were taken by tagging 1-yearold dominant shoot axis on three trees (25 shoots on each tree) and percent lateral bearing was recorded by counting total leafy shoots and floriferous leafy shoots on 1-year-old shoot and converted into percent lateral bearing (IPGRI, 1994, Arzani et al., 2008). The annual extension growth of dominant shoot axis was recorded using scale.

\subsection{Characterization and yield quantification}

Characterization was carried out by adopting walnut descriptors of International Plant Genetic Resource Institute (IPGRI, 1994). The most widely grown indigenous varieties, 'Sulaiman' and 'Hamdan' (both are terminal bearer) released from Sher-e-Kashmir University of Agricultural Science and Technology, Srinagar (Bhat and Ahmad, 2002) were used as local checks for comparison. For characterization, the observations were made on various characters viz., tree vigor, growth habit, branching density and bearing habit during dormant season in the field. Shell characteristics (Texture, colour, seal, strength and integrity), nut characteristics (shape, weight, length, diameter, thickness, shell thickness) and kernel characteristics (weight, recovery, colour, fill and plumpness) were recorded in laboratory. All the observations were recorded according to IPGRI descriptor except branching density, which was made according to UPOV (1998) descriptor. The nut traits were recorded on 20 randomly collected nuts. Trunk circumference was recorded $20 \mathrm{~cm}$ above graft union and converted into trunk cross section area. Yield efficiency was calculated as the ratio between nut yield (g) and trunk cross sectional area (TCSA in $\mathrm{cm}^{2}$ ).

\subsection{Statistical analysis}

Data were subjected to a one-way analysis of variance (ANOVA) and statistically compared by Duncan's multiple range tests (DMRT) using SPSS 16.0 software.

\section{Results and Discussion}

\subsection{Identification and quantification of lateral bearing}

Among studied accessions, only one accession CITH-W-121 (IC-0622836) was found with lateral bearing trait and a few with intermediate bearing and rest were terminal bearer. In this accession, leafy shoot were developed from terminal, sub terminal as well as from majority of the lateral buds in the axils of past season leaves and total $49.89 \%$ (mean) lateral leafy shoots of tagged shoots were terminated in pistillate inflorescence with 1-3 fruits. Overall 40-60\% lateral leafy shoots were reported with fruiting. Rest leafy shoots remained vegetative, but provided more fruiting points inside canopy on 2-3 year wood in later years. This type of fruiting 
pattern is helpful in maintaining regularity in production. Male catkins developed from 2-4 basal buds of the 1-yearold shoot. Morphology of lateral bearing branch of accession CITH-W-121 is given in Figure 1A. Annual extension growth of the dominant axis was significantly lower in CITH-W-121 $(40.07 \mathrm{~cm})$ as compared to Sulaiman $(60.06 \mathrm{~cm})$ and Hamdan $(51.32 \mathrm{~cm})$ as given in table 1 and comparison has been given in figure $1 \mathrm{~B}$ and $1 \mathrm{C}$. The probable reason of induction of more lateral branches may be due to weak apical dominance as result showed. Akca and Ozongun (2004) have also reported 10-70\% lateral bearing with 1-3 nuts per inflorescence in Turkish origin genotypes. Solar et al. (2001) estimated budderived IAA in terminal bearer (Franquette) and lateral bearer (Lara) cultivars and found that bud-derived IAA concentration was influenced by the cultivar (Franquette had 3.6 times more

Table 1: Growth and yield related traits of accession CITH-W-121 with local checks (pooled data of two years)

\begin{tabular}{|c|c|c|c|c|}
\hline Accession & $\begin{array}{c}\text { MAEGDA } \\
(\mathrm{cm})\end{array}$ & $\begin{array}{l}\text { Yield (kg } \\
\text { tree }^{-1} \text { ) }\end{array}$ & $\begin{array}{l}\text { TCSA } \\
\left(\mathrm{cm}^{2}\right)\end{array}$ & $\begin{array}{l}\text { Yield efficien- } \\
\text { cy }\left(\mathrm{g} \mathrm{sq} \cdot \mathrm{cm}^{-1}\right)\end{array}$ \\
\hline CITH-W-121 & $40.07^{\text {a\# }}$ & $11.07^{a}$ & $419.81^{b}$ & $26.37^{a}$ \\
\hline Sulaiman & $60.06^{c}$ & $5.85^{b}$ & $606.18^{\mathrm{a}}$ & $9.65^{c}$ \\
\hline Hamdan & $51.32^{\mathrm{b}}$ & $5.48^{\mathrm{b}}$ & $392.20^{c}$ & $13.99^{b}$ \\
\hline SEm \pm & 2.36 & 0.92 & 102.48 & 2.52 \\
\hline $\begin{array}{l}\text { Mean @ 5\% } \\
\text { los }\end{array}$ & 50.48 & 7.47 & 472.73 & 16.67 \\
\hline
\end{tabular}

MAEGDA: Mean annual extension growth of the dominant axis; "letters indicate the statistical difference within same column at $5 \%$ level of significance

cumulative IAA along the 1-year-old shoot than Lara) with denser branching in Lara than Franquette.

\subsection{Yield quantification}

The yield related traits of CITH-W-121 were compared with local checks viz., Hamdan and Sulaiman (Table 1). In terms of yield, CITH-W-121 (11.07 kg tree ${ }^{-1}$ ) was found significantly superior to Sulaiman $\left(5.85 \mathrm{~kg}^{\mathrm{g}} \mathrm{tree}^{-1}\right)$ and Hamdan $(5.48 \mathrm{~kg}$ tree $\left.{ }^{-1}\right)$. The reason of higher yield may be due to very high branching density and more laterals contributing to higher fruiting buds. There was not much alteration in yield in two consecutive years, which may be due to some leafy laterals remain vegetative in one year and produce reproductive buds in next year. Yield efficiency was recorded significantly higher in CITH-W-121 (26.37 $\mathrm{g} \mathrm{cm}^{-2}$ TCSA) over the two ruling check varieties i.e, Hamdan (13.99 $\mathrm{g} \mathrm{cm}^{-2}$ TCSA) and Sulaiman (9.65 g $\mathrm{cm}^{-2}$ TCSA). Solar et al. (2014) reported yield efficiency of 0.37 and $0.26 \mathrm{~kg} \mathrm{~cm}^{-2}$ TCSA in 14 year old trees of Sava and Krka cultivars having $50-86 \%$ lateral bud fruitfulness, respectively. Arzani et al. (2008) recorded yield efficiency between $0.07-24.73 \mathrm{~g} \mathrm{~cm}^{-2}$ TCSA in walnut accessions originated from Central Iran.

\subsection{Characterization}

The nut and kernel traits of CITH-W-121 are presented in table 2 along with local checks (Hamdan and Sulaiman). The accession CITH-W-121 recorded mean nut weight (15.02 g), kernel weight $(7.51 \mathrm{~g})$, which was at par with Hamdan (14.26 $\mathrm{g}$ and $8.54 \mathrm{~g}$ respectively) while kernel recovery $(49.94 \%)$ was at par with Sulaiman $(48.00 \%)$. This accession has desirable traits like well filled, plump and light coloured kernel and moderately easy to remove kernel halves. Nut thickness (36.04 $\mathrm{mm})$, nut length $(35.37 \mathrm{~mm})$ and nut diameter $(38.49 \mathrm{~mm})$ of CITH-W-121 was significantly different from both the checks while shell thickness $(2.03 \mathrm{~mm})$ of CITH-W-121 was at par with Sulaiman (2.03 mm). McGranahan and Leslie (2006) had described the criteria for ideal walnut cultivars. According to them, a walnut variety would have lateral bearing, relatively large or jumbo nut, smooth and well-sealed nut shell, plump and light colour kernels weighing about $7-8 \mathrm{~g}$, at least $50 \%$ kernel recovery and come out easily in halves. Most of the traits of the accession CITH-W-121 are in line with the above description. These results are in agreement with Akca and Ozongun (2004). Moreover, the value of nut weight, kernel weight of accession CITH-W-121 was higher than reported by Akca and Ozongun (2004) in Turkish origin genotypes having lateral bearing between $10-70 \%$. However, the kernel weight and kernel recovery of $\mathrm{CITH}-\mathrm{W}-121$ were higher than major Californian lateral bearing cultivars such as Ashley, Chico, Vina, Pedro, Howard, Chandler, Cisco (Hendricks et al.,

Table 2: Quantitative nut and kernel traits of accession CITH-W-121 with local checks (mean of two years)

\begin{tabular}{lccccccc}
\hline Accession & $\mathrm{NW}(\mathrm{g})$ & $\mathrm{KW}(\mathrm{g})$ & $\mathrm{KR}(\%)$ & $\mathrm{NT}(\mathrm{mm})$ & $\mathrm{NL}(\mathrm{mm})$ & $\mathrm{ND}(\mathrm{mm})$ & $\mathrm{ST}(\mathrm{mm})$ \\
\hline CITH-W-121 & $15.02^{\mathrm{bH}}$ & $7.51^{\mathrm{b}}$ & $49.94^{\mathrm{b}}$ & $36.04^{\mathrm{b}}$ & $35.37^{\mathrm{b}}$ & $38.49^{\mathrm{b}}$ & $2.08^{\mathrm{b}}$ \\
Sulaiman & $22.12^{\mathrm{a}}$ & $10.63^{\mathrm{a}}$ & $48.00^{\mathrm{b}}$ & $39.94^{\mathrm{a}}$ & $44.31^{\mathrm{a}}$ & $43.97^{\mathrm{a}}$ & $2.03^{\mathrm{b}}$ \\
Hamdan & $14.26^{\mathrm{b}}$ & $8.54^{\mathrm{b}}$ & $59.94^{\mathrm{a}}$ & $34.61^{\mathrm{c}}$ & $45.12 \mathrm{a}$ & $36.19^{\mathrm{c}}$ & $1.22^{\mathrm{a}}$ \\
Mean & 17.13 & 8.89 & 52.63 & 36.86 & 41.60 & 39.55 & 1.78 \\
SEm \pm & 0.99 & 0.40 & 1.52 & 0.62 & 1.21 & 0.89 & 0.11 \\
\hline
\end{tabular}

\#letters indicate the statistical difference within same column at $5 \%$ level of significance; Abbreviation: NW-nut weight; KWkernel weight; KR-kernel recovery; NT-nut thickness; NL-nut length; ND-Nut diameter; ST-shell thickness 
1998). Zhadan and Strukov (1977) stated that desirable shell thickness should vary between 0.7 and $1.5 \mathrm{~mm}$. Higher shell thickness of CITH-W-121 may be the probable reason for slight lesser kernel recovery. Number of nuts per inflorescence (1-3) was found similar with checks (Table 3 ). These results are in line with previous studies (McGranahan and Leslie, 1991; Akca and Ozongun, 2004). The tree vigour was high with spreading growth habit having side branches spreading upward without competing with central leader (Table 3; Figure 1D and 1E). The branching density was observed very dense in CITH-W-121 in relation to others (Table 3; Figure $1 \mathrm{~B}$ and $1 \mathrm{C}$ ). In comparison to check varieties, CITH-W-121 had short trapezoid nut shape, light shell with medium texture, complete shell integrity, intermediate shell seal and shell strength. Yield potential in walnut depends on bearing habit, number of fruit on terminal and lateral shoots, lateral fruitfulness, nut weight, kernel ratio, and nut size (McGranahan and Leslie, 1991; Akca and Ozongun, 2004)

Table 3: Descriptive traits of accession CITH-W-121 with local checks

\begin{tabular}{|c|c|c|c|}
\hline Traits & CITH-W-121 & Sulaiman & Hamdan \\
\hline Tree vigour & High & Very high & High \\
\hline Tree growth habit & Spreading & $\begin{array}{l}\text { Semi- } \\
\text { erect }\end{array}$ & Spreading \\
\hline Branching density & Very dense & Medium & Dense \\
\hline Bearing habit & Lateral & Terminal & Terminal \\
\hline Lateral bearing (\%) & $49.89 \%$ & - & - \\
\hline Fruits per panicle & $1-3$ & $1-3$ & $1-3$ \\
\hline Shell colour & Light & Light & Very light \\
\hline Shell texture & Medium & Rough & Smooth \\
\hline Shell strength & $\begin{array}{l}\text { Intermedi- } \\
\text { ate }\end{array}$ & $\begin{array}{l}\text { Interme- } \\
\text { diate }\end{array}$ & Weak \\
\hline Shell seal & $\begin{array}{l}\text { Intermedi- } \\
\text { ate }\end{array}$ & $\begin{array}{l}\text { Interme- } \\
\text { diate }\end{array}$ & $\begin{array}{l}\text { Intermedi- } \\
\text { ate }\end{array}$ \\
\hline Shell integrity & Complete & $\begin{array}{l}\text { Com- } \\
\text { plete }\end{array}$ & $\begin{array}{l}\text { Intermedi- } \\
\text { ate }\end{array}$ \\
\hline Nut shape & $\begin{array}{l}\text { Short trap- } \\
\text { ezoid }\end{array}$ & Ovate & Ovate \\
\hline Kernel colour & Light & Light & Light amber \\
\hline Kernel fill & Well & $\begin{array}{l}\text { Moder- } \\
\text { ate }\end{array}$ & Well \\
\hline Kernel plumpness & Plump & $\begin{array}{l}\text { Moder- } \\
\text { ate }\end{array}$ & Plump \\
\hline $\begin{array}{l}\text { Ease in removal of } \\
\text { kernel halves }\end{array}$ & Moderate & Easy & Very easy \\
\hline
\end{tabular}
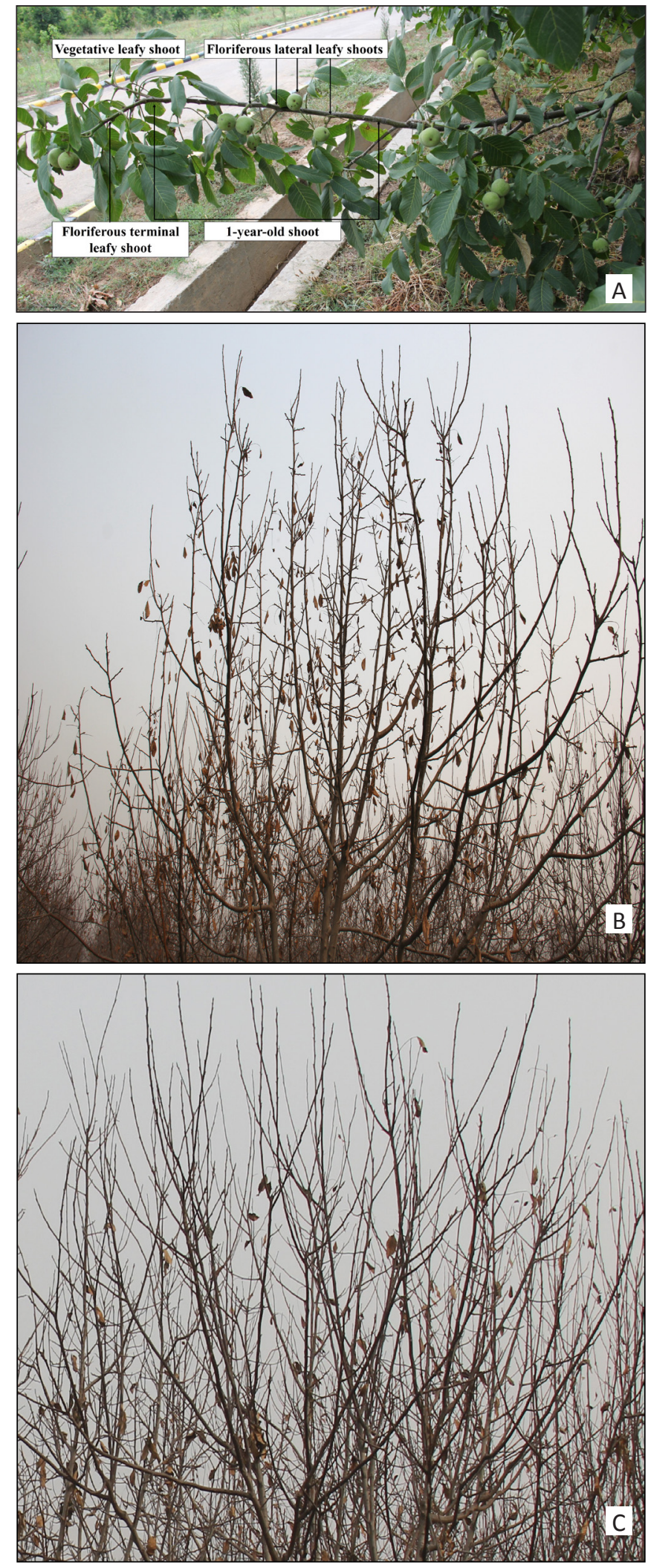

Figure 1: A: Morphology of fruit bearing branch of CITH-W-121; $B$ and $C$ : Showing difference in branching density and annual extension growth of dominant axis's in lateral (CITH-W-121) and terminal bearer (Sulaiman),

Continue... 

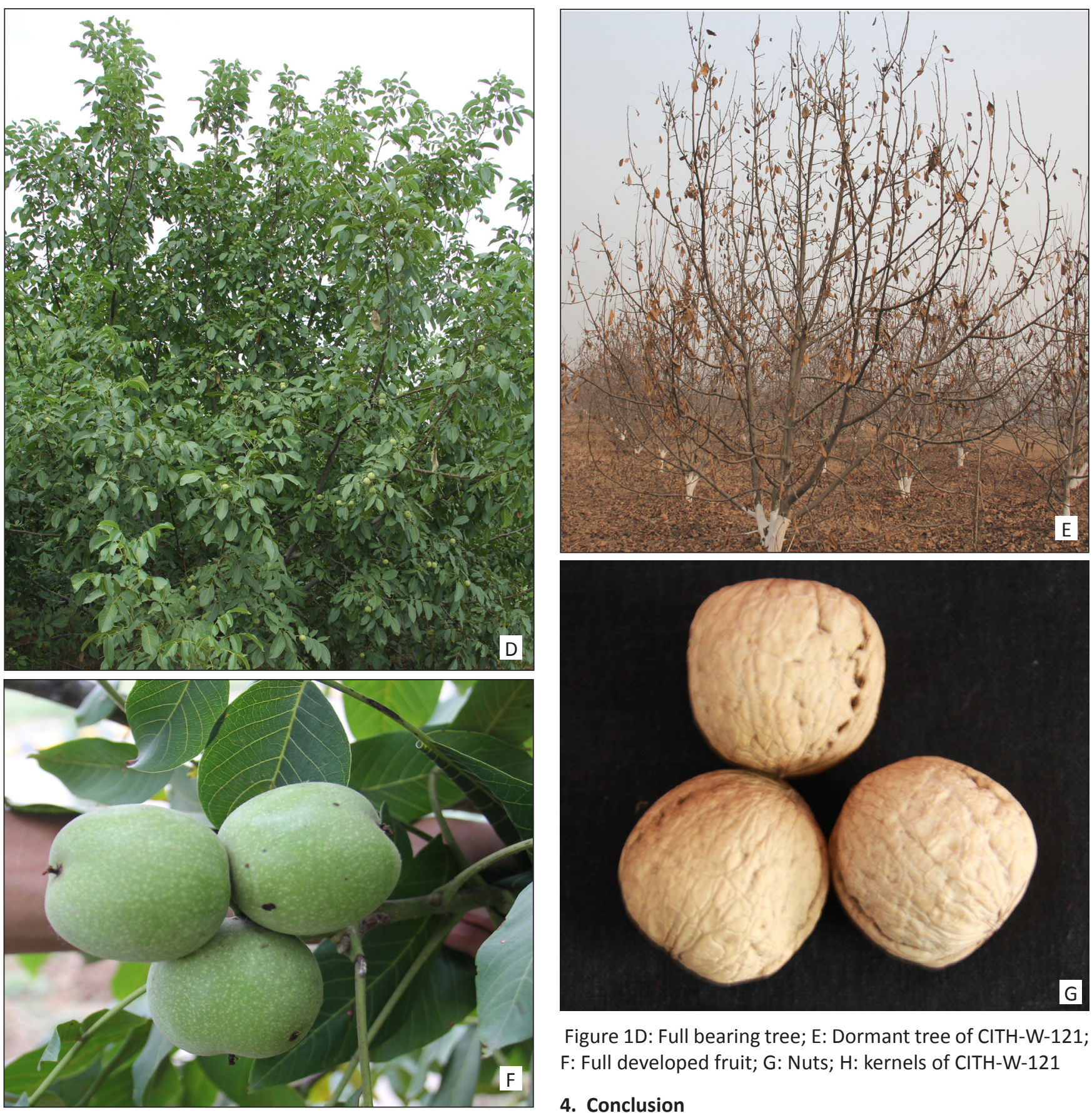

Figure 1D: Full bearing tree; E: Dormant tree of CITH-W-121; F: Full developed fruit; G: Nuts; H: kernels of CITH-W-121

\section{Conclusion}

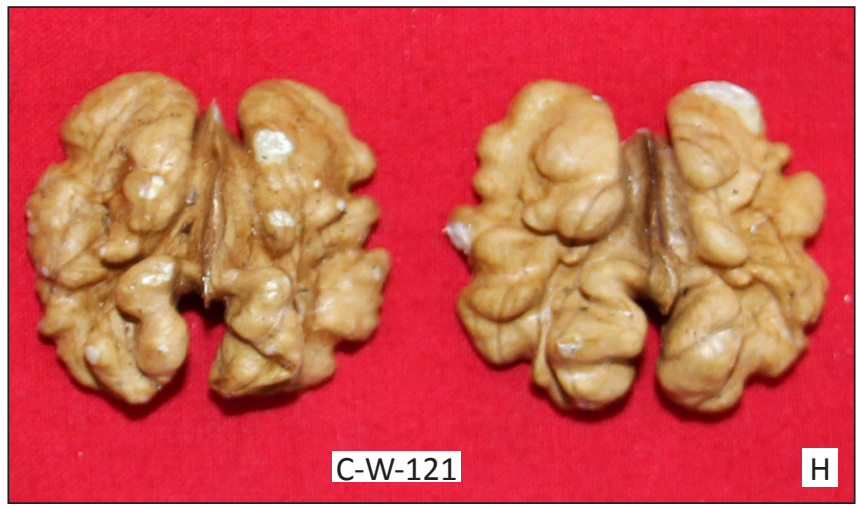

In walnut, lateral bearing is an important trait, which is associated with precocity and higher yield from early age of tree. The accession CITH-W-121 was identified as lateral bearer with mean nut weight $15.02 \mathrm{~g}$, kernel weight $7.51 \mathrm{~g}$ and 11.07 $\mathrm{kg}$ tree $^{-1}$ mean yield of dried nut was obtained from 15 year old tree. The lateral bud fruitfulness and dense branching were main contributing factors for higher yield in CITH-W-121. This genotype could be released as variety if found satisfactory in multi-location trails. It also a potential parent for lateral bearing trait which can be transferred into superior terminal bearer varieties through hybridization. 


\section{References}

Akca, Y., Ozongun, S., 2004. Selection of late leafing, late flowering, laterally fruitful walnut (Juglans regia) types in Turkey. New Zealand Journal of Crop and Horticultural Science 32, 337-342.

Arzani, K., Mansouri-Ardakan, H., Vezvaei, A., Roozban M.R., 2008. Morphological variation among Persian walnut (Juglans regia L.) genotypes from central Iran. New Zealand Journal of Crop and Horticultural Science 36, 159-168.

Bhat, A.R., Ahmad, M.F., 2002. Hamdan and Sulaiman-New Walnut varieties for North Western Himalyas. Indian Horticulture 47, 33-34.

Ducousso, I., Sabatier, S., Barthelemy, D., Germain, E., 1995.Comparison de quelques caracteristiques morphologiques des pousses annuelles et des branches de la cime de sept varietes de Noyer commun, Juglans regia L. (Juglandaceae). In: Les Coloques, No.74. Colloque Architecture des arbres fruitie reset forestieres Montpellier, France, 91-108.

Fernandez-Lopez, J., Aleta, N., Alıas, R., 2000. Forest genetic resources conservation of Juglans regia L. IPGRI Publishers, Rome, Italy, 20-25.

Forde, H.I., 1979. Persian walnut in the western United States. In: Jaynes, R.A. (Ed.), Nut tree culture in North America. Hamden, Connecticut, North Nut Growers Association, 84-97.

Germain, E., 1990. Inheritance of late leafing and lateral bud fruitfulness inwalnut (Juglans regia L.), phenotypic correlations among some traits of the trees. Acta Horticulturae 284, 125-134.

Germain, E., 1992. Le noyer. In: Gallais, A., Bannerot, H. (Eds.), Ame Alorationdesespecesve Age Atalescultive Aes, objectifsetcrite Ares de se Alection. Paris, INRA, France 125-134.

Hendricks, L.C., Coates, W.W., Elkins, R.B., McGranahan, G.H., Phillips, H.A., Ramos, D.E., Reil, W.O., Snyder, R.G., 1998. Selection of varieties. In Walnut production manual, University of California, USA, 84-89.

IPGRI, 1994. Descriptors for walnut (Juglans spp.). International Plant Genetic Resources Institute, Rome, Italy.

Laurens, F., Audergon, J., Claverie, J., Duval, H., Germain, E., Kervella, J., Le Lezec, M., Lauri, P., Lespinasse, J. 2000. Integration of architectural types in French programmes of ligneous fruit species genetic improvement. Fruits 55, 141-152.

McGranahan, G.H., Leslie, C.A., 2006. Advances in Genetic Improvement of Walnut at the University of California, Davis. In: Malvolti, M.E., Avanzato, D. (Eds.), Proceedings $V^{\text {th }}$ Int. Walnut Symp. Acta Horticulturae 705, 117-122.

McGranahan, G.H., Leslie, C., 1991. Walnuts 'Juglans regia'. Acta Horticulturae 290, 901-951.
McGranahan, G.H., Leslie, C., 2009. Breeding Walnuts (Juglans Regia). In: Jain, S.M., Priyadarshan, P.M. (Eds.), Breeding Plantation Tree Crops: Temperate Species (Springer Science+Business Media, LLC, 233 Spring Street, New York, NY 10013, USA), 249-273.

Pandey, G., Tripathi, A.N., Verma, M.K., Sofi, A.A., 2004. Collection, characterization and evaluation of walnut (Juglans regia L.) germplasm from North-Western Himalayas. Indian Journal of Plant Genetic Resources 17(1), 77-80.

Rana, J.C., Singh, D., Yadav, S.K., Verma, M.K., Kumar, K., Pradheep, K., 2007. Genetic diversity collected and observed in Persian walnut (Juglans regia L.) in the western Himalaya region of India. Plant Genetics Resources Newsletter 151, 63-68.

Serr, E.F., 1962. Selecting suitable walnut varieties. California Agricultural Experiment Station, Davis, California, Leaf 144.

Sharma, O.C., Murkute, A.A., Kanwar, M.S., 2010. Assessing genetic divergence in seedling trees of Persian walnut (Juglans regia). Indian Journal of Agricultural Sciences 80(5), 360-363.

Sharma, O.C., Sharma, S.D., 2001. Genetic divergence in seedling trees of Persian walnut (Juglans regia L.) for various metric nut and kernel characters in Himachal Pradesh. Scientia Horticulturae 88(2), 163-171.

Sharma, S.D., Sharma, O.C., 1998. Studies on the variability in nuts of seedling walnuts (Juglans regia L.) in relation to the tree age. Fruit Varieties Journal 52 (1), 20-23.

Solar, A., Hudina, M., Stampar, F., 2001. Relationship between tree architecture, phenological data and generative development in walnut (Juglans regia L.). Acta Horticulturae 544, 275-286.

Solar, A., Hudina, M., Stampar, F., 2004. Fruiting Habit and Branching Pattern Affect Vegetative Growth and Reproductive Ability in Walnut (Juglans regia L.). In: Laurens, F., Evans, K. (Eds.), XIth Eucarpia Symposium on Fruit Breeding \& Genetics. Acta Horticulturae 663, 387-392.

Solar, A., Osterc, G., Stampar, F., Kelc, D., 2011. Branching of annual shoots in common walnut (Juglans regia L.) as affected by bud production and indol-3-acetic acid (IAA) content. Trees25(6), 1083-1090.

Solar, A., Robert, V., Franci, S., 2014. 'Sava' and 'Krka' walnut cultivars. HortScience 49(8), 1081-1082.

UPOV, 1988. Union internationale pour le protection des obtentionsvegetales. Draft guidelines for the conduct of tests for distinctness homogeneity and stability. Walnut (Juglans regia L.). UPOV, Geneva, Switzerland.

Zhadan, V.M., Strukov, M.V., 1977. Breeding walnut for fruit size. Plant breeding abstracts 47(11), 918. 